\title{
Study on the Effect of Production Parameters and Raw Materials Used on the Mechanical Properties of Leaded Brass (CuZn40Pb2) Alloy
}

\author{
Abdulsalam A. Fadhil1,2*, Tawakol A. Enab'1, Magdy Samuel1, Berlanty A. Iskander3, \\ Sami A. Ajeel ${ }^{4}$ \\ ${ }^{1}$ Production Engineering and Mechanical Design Department, Faculty of Engineering, Mansoura University, Mansoura, Egypt \\ ${ }^{2}$ General Company of Copper and Mechanical Industries, Ministry of Industry \& Minerals, Iraq \\ ${ }^{3}$ Production Engineering Department, American University, Cairo, Egypt \\ ${ }^{4}$ Production Engineering Department, University of Technology, Iraq \\ Email: *aabbaltimimy@yahoo.com
}

How to cite this paper: Fadhil, A.A., Enab, T.A., Samuel, M., Iskander, B.A. and Ajeel, S.A. (2017) Study on the Effect of Production Parameters and Raw Materials Used on the Mechanical Properties of Leaded Brass (CuZn40Pb2) Alloy. World Journal of Engineering and Technology, 5, 340-349. https://doi.org/10.4236/wjet.2017.52028

Received: April 15, 2017

Accepted: May 24, 2017

Published: May 27, 2017

Copyright (c) 2017 by authors and Scientific Research Publishing Inc. This work is licensed under the Creative Commons Attribution International License (CC BY 4.0).

http://creativecommons.org/licenses/by/4.0/

\begin{abstract}
Leaded brass alloys used progressively in many applications such as gas valves production owing to their excellent machinability, corrosion resistance and some other specifications. However, the production processes of these alloys involve some problems appearing in the last activities of production as a result of cumulative defects of previous production processes. Therefore, the current investigation studies the effect of process parameters during casting, hot extrusion and cold drawing production stages of $\mathrm{CuZn} 40 \mathrm{~Pb} 2$ leaded brass alloy on the mechanical properties. Starting with casting process, two types of charges were used. The first charge consists of $100 \%$ recycles while the second contains $30 \%$ of pure materials such as $\mathrm{Cu}, \mathrm{Zn}$ and $\mathrm{Pb}$ in addition to the recycles. For each production stage, alloy hardness, micro-hardness, ultimate tensile strength and elongation were examined. The results illustrated that high hardness values are obtained during casting process due to some impurities such as iron and the effect of cooling rate through solidification. The hardness values decrease during extrusion process and then rise again by cold drawing for the charge of $30 \%$ pure materials. Micro-hardness values for the fractured tensile test samples appeared higher than others due to work hardening effect. The best mechanical properties as ultimate tensile strength of $\mathrm{CuZn} 40 \mathrm{~Pb} 2$ alloy products are appeared into cold forming samples with the $30 \%$ pure material added.
\end{abstract}

\section{Keywords}

Leaded Brass Alloy, Mechanical Properties, Hardness, Work Hardening 


\section{Introduction}

Brasses with $58 \%$ or $59 \%$ of $\mathrm{Cu}$ in addition to some extent of lead are suitable for metal strips, bands, and bars production. At higher temperatures, it is possible to apply forging and pressing to these brasses. These alloys are difficult to cold form, while they can be forged [1]. Brass in the $\alpha$ - $\beta$ range (free machining brass) has excellent hot workability [2]. To improve the required characteristics of brass alloys, some alloying elements are added. For example, copper machinability can be improved by adding lead, sulfur, tellurium and zinc. Lead in brass alloys with concentrations around $2 \mathrm{wt} \%$ improves machinability by acting as a microscopic chip breaker and tool lubricant, while they increase the brittleness of the alloy [3]. On the contrary, adding alloying elements such as tin and iron affect negatively to the brass machinability [4].

Machinable brasses are manufactured by hot extrusion and cold drawing, and serve as raw materials for the production of a broad range of products, such as bolts, nuts, electrical connectors, valve bodies, and hydraulic fittings. Moreover, leaded brass rods are widely used in applications varying from decoration and architecture to electrical/electronic and structural systems. The production of the final components involves various machining operations, such as drilling, milling, and turning [5] [6].

The strength and formability of extruded brass rods are strongly affected by the hot extrusion parameters which determine the grain sizes and the textures of extruded products. Additionally, in the case of $\mathrm{CuZn} 40 \mathrm{~Pb} 2$, multiple phase transformations arise during the hot extrusion process and affect the resulting properties [7]. Many technological parameters and forming tools have an influence on the hot extrusion process of brass. The most important technological parameters of the extrusion process include: the speed of extrusion, extrusion ratio, average shear strain rate, the temperature of extrusion and the suitable preheating of forming tools. Manufacturing experience with hot extrusion process shows that alpha and beta leaded brasses $(\mathrm{CuZn} 40 \mathrm{~Pb} 2)$ are perfectly suitable for the extrusion process [8]. The material microstructure is highly affected by the production processes parameters and usually influences the properties of the material since any variation in microstructure can significantly change the strength, toughness, hardness, ductility and even thermal and electrical properties [9].

Therefore, the current investigation aims to study the effect of production parameters and the alloy constituents of raw materials on the mechanical properties of leaded brass $(\mathrm{CuZn40Pb2)}$ alloy which are used in gas valves production. Two brass alloys charges are considered; i.e. charge contains $30 \%$ of pure materials in addition to the recycled materials while the other is totally consisted of recycled materials.

\section{Materials and Methods}

The methodology used to carry out this work involves studying of leaded brass $(\mathrm{CuZn} 40 \mathrm{~Pb} 2)$ alloy as casted billets, extruded rods and cold drawn rods. Leaded 
brass alloy $(\mathrm{CuZn} 40 \mathrm{~Pb} 2)$ which consist of copper, zinc and lead is selected according to European Standards (EN), CW617N as shown in Table 1, to produce the castings required for the experimental work.

\section{Material Preparation}

\subsection{Melting and Casting Processes}

Melting and casting processes of $\mathrm{CuZn} 40 \mathrm{~Pb} 2$ alloy carried out with two types of casting alloys depending on charge materials and the casting parameters. The first alloy produced by using $100 \%$ recycles as charge materials. CuZn $40 \mathrm{~Pb} 2$ alloy recycle of gas valves for about $3000 \mathrm{~kg}$ are sequentially charged into coreless induction furnace. The melting point of the alloy mixture is located between 875 and $890^{\circ} \mathrm{C}$ according to equilibrium diagram of copper-zinc alloy [11]. Temperature of molten alloy increased to $1050^{\circ} \mathrm{C}$ and then chemical composition of alloy is estimated. The molten alloy temperature increased again to $1100^{\circ} \mathrm{C}$ as pouring temperature before pour the melt into casting mold of a vertical semicontinuous casting machine. The molten alloy in casting mold covered with powder flux called "Cuprit 103" which is a white powder used as a protective cover on molten metal during the casting process. This protective cover will prevent any contaminations and will produce oil lubricant for mold liner after melt by molten metal [12]. The casting parameters used for this alloy are illustrated in Table 2 which adopted according to the technical knowhow of the supplying company.

The second alloy produced by using $70 \%$ recycles in addition to $30 \%$ of pure materials such as $\mathrm{Cu}, \mathrm{Zn}$ and $\mathrm{Pb}$ added as charge materials. The production process for the second $\mathrm{CuZn} 40 \mathrm{~Pb} 2$ casting alloy is performed by repeating the same production processes adopted for the first alloy except some changes adopted in casting parameters as illustrates in Table 2. The final products of

Table 1. Chemical composition of $\mathrm{CuZn} 40 \mathrm{~Pb} 2$ alloy according to EN standards [10].

\begin{tabular}{cccccccccc}
\hline Element $\%$ & $\mathrm{Cu}$ & $\mathrm{Zn}$ & $\mathrm{Sn}$ & $\mathrm{Al}$ & $\mathrm{Pb}$ & $\mathrm{Ni}$ & $\mathrm{Si}$ & $\mathrm{Fe}$ & Others \\
\hline Max. & 59 & Rem. & 0.3 & 0.05 & 2.5 & 0.3 & -- & 0.3 & 0.2 \\
Min. & 57 & & & & 1.6 & & & & \\
\hline
\end{tabular}

Table 2. Casting parameters of the two CuZn40Pb2 alloys.

\begin{tabular}{|c|c|c|c|}
\hline & Alloy Batch No. & 1 & 2 \\
\hline \multirow{7}{*}{ 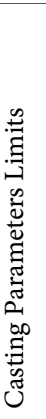 } & Charge material & $\begin{array}{c}100 \% \text { recycle } \\
\text { (used gas valves) }\end{array}$ & $\begin{array}{c}30 \% \text { pure materials }+ \\
70 \% \text { recycle }\end{array}$ \\
\hline & Pouring Temperature $\left({ }^{\circ} \mathrm{C}\right)$ & $1050-1100$ & $1000-1050$ \\
\hline & Casting Speed (mm/min.) & 200 & 180 \\
\hline & Vibration of casting mold (cycle/min.) & $80-100$ & $80-100$ \\
\hline & Primary cooling water $\left(\mathrm{m}^{3} / \mathrm{hr}\right.$.) & 5 & 4 \\
\hline & Secondary cooling water $\left(\mathrm{m}^{3} / \mathrm{hr}\right.$.) & 3 & 3 \\
\hline & Inlet cooling water temperature $\left({ }^{\circ} \mathrm{C}\right)$ & $25-30$ & $25-30$ \\
\hline
\end{tabular}


casting processes are two strands of leaded brass alloy billets of $180 \mathrm{~mm}$ diameter and $6000 \mathrm{~mm}$ length.

\subsection{Extrusion and Cold Drawing Processes}

Samples of $180 \mathrm{~mm}$ diameter and $300 \mathrm{~mm}$ length prepared from the previously produced castings billets of the two alloys types. These samples are heated by induction furnace before extruded. Extrusion process carried out experimentally under two different extrusion conditions cases Table 3, to produce two extruded leaded brass rods of $32.2 \pm 0.2 \mathrm{~mm}$ diameter in each extrusion action. The extruded rods after pickling and oxidation removing are cold drawn by hydraulic draw bench to produce (

\section{Mechanical Testing and Inspections}

Numerous types of experimental inspection and test processes are carried out to acquire the mechanical properties of proposed $\mathrm{CuZn} 40 \mathrm{~Pb} 2$ alloys for pressurized gas valves production. Samples are collected from each stage of production processes (i.e. casting, extrusion and cold drawing). These samples are named and described depending on charge materials, location within the billet and production conditions adapted as illustrated in Table 4. After that, tensile, hardness and micro-hardness tests are carried out. In addition, some specimens are taken from the tensile test samples after their fracture to check the micro-hardness.

\subsection{Hardness Test}

The above mentioned fourteen samples (see Table 4) collected after casting, hot extrusion and cold drawing production processes under different conditions are grinded and polished carefully. A programmable hardness device (AFFRI 251 VRSD) is used to check and calculate the hardness of samples. Brinell hardness measured for each sample using $5 \mathrm{~mm}$ diameter ball indenter and an applied load of $62.5 \mathrm{~N}$. The indenter mark pictures and diameters are calculated by optical lenses which equipped with hardness device, and then the hardness values are estimated and displayed onto the device screen. For each sample, three hardness measurements are taken and averaged to reflect its hardness value.

\subsection{Tensile and Elongation Test}

The tensile tests are accomplished for hot extruded and cold drawn rods sam-

Table 3. Hot extrusion conditions of CuZn40Pb2 alloys.

\begin{tabular}{ccc}
\hline Type of Parameters & Case 1 & Case 2 \\
\hline Preheating temperature of extrusion billet & $700^{\circ} \mathrm{C}$ & $650^{\circ} \mathrm{C}$ \\
Preheating temperature of extrusion dies & $400^{\circ} \mathrm{C}-450^{\circ} \mathrm{C}$ & $400^{\circ} \mathrm{C}-450^{\circ} \mathrm{C}$ \\
Extrusion speed & $27 \mathrm{~mm} \backslash \mathrm{sec}$. & $30 \mathrm{~mm} \backslash \mathrm{sec}$. \\
Extrusion ratio & 17 & 17 \\
\hline
\end{tabular}


Table 4. Samples names and their descriptions.

\begin{tabular}{|c|c|c|c|c|}
\hline \multirow{2}{*}{$\begin{array}{c}\text { Sample } \\
\text { No. }\end{array}$} & \multicolumn{4}{|c|}{ Description } \\
\hline & Process Type & Sample Location & Charge Material & Parameters Condition \\
\hline 1 & Casting & Right side of billet & $100 \%$ recycle & Before improvement \\
\hline 2 & Casting & Center of billet & $100 \%$ recycle & Before improvement \\
\hline 3 & Casting & Left side of billet & $100 \%$ recycle & Before improvement \\
\hline 4 & Casting & Right side of billet & $30 \%$ pure material $+70 \%$ recycle & After improvement \\
\hline 5 & Casting & Center of billet & $30 \%$ pure material $+70 \%$ recycle & After improvement \\
\hline 6 & Casting & Left side of billet & $30 \%$ pure material $+70 \%$ recycle & After improvement \\
\hline 7 & Extrusion & --- & $100 \%$ recycle & Before improvement \\
\hline 8 & Extrusion & --- & $100 \%$ recycle & After improvement \\
\hline 9 & Extrusion & --- & $30 \%$ pure material $+70 \%$ recycle & Before improvement \\
\hline 10 & Extrusion & --- & $30 \%$ pure material $+70 \%$ recycle & After improvement \\
\hline 11 & Drawing & --- & $100 \%$ recycle & Before improvement \\
\hline 12 & Drawing & --- & $100 \%$ recycle & After improvement \\
\hline 13 & Drawing & --- & $30 \%$ pure material $+70 \%$ recycle & Before improvement \\
\hline 14 & Drawing & --- & $30 \%$ pure material $+70 \%$ recycle & After improvement \\
\hline
\end{tabular}

ples. Standard tensile test samples are machined according to ASTM E8M [13] on turning machine (VDEST-AIRINE, DA 300 MASEHINE type), and then grinded with abrasive paper of grade $2000 \mu \mathrm{m}$. Tests carried out at Mechanics of Materials Laboratory-American University-Cairo-Egypt, using a programmable tensile test device (INSTRON 3382 type) which has a capacity of $100 \mathrm{KN}$. Two groups of tensile test specimens are considered. The first group contains four specimens of $9 \mathrm{~mm}$ gage diameter while the other consists of four specimens with $6 \mathrm{~mm}$ gage diameter. The ultimate tensile strength and elongation of samples measured and the stress-strain curves are obtained.

\subsection{Micro-Hardness Test}

This test is performed only for the eight specimens obtained from the extruded (specimens 7 to 10) and cold drawn (specimens 11 to 14) processes after their fracture under the tensile test process. The micro-hardness values for the samples are checked using testing device LECO CORPERATION type, model 251 VRSD, 115\230 Volt. The load used is (100) gf and 10 seconds as dwell time. The test locations are selected on the surface and center of samples to explain the difference of hardness values between these locations. Three points of test values for each location on the sample are measured and then, the averages of these hardness values are estimated.

\section{Results and Discussions}

The results of this study include some mechanical test and inspection processes such as Brinell hardness (HB), micro-hardness (HV), ultimate tensile strength 
and elongation test results. These mechanical tests and inspection results will be illustrated and discussed in the subsequent paragraphs.

\subsection{Hardness and Micro-Hardness Test Results}

Table 5 presents the Brinell (HB) and Vickers (HV) hardness results for the collected specimens at different production stages. Noting that, Vickers hardness (HV) values obtained from Brinell hardness (HB) values according to ASTM E140-02 [14]. Moreover, Figure 1 shows the hardness values of all tested speci-

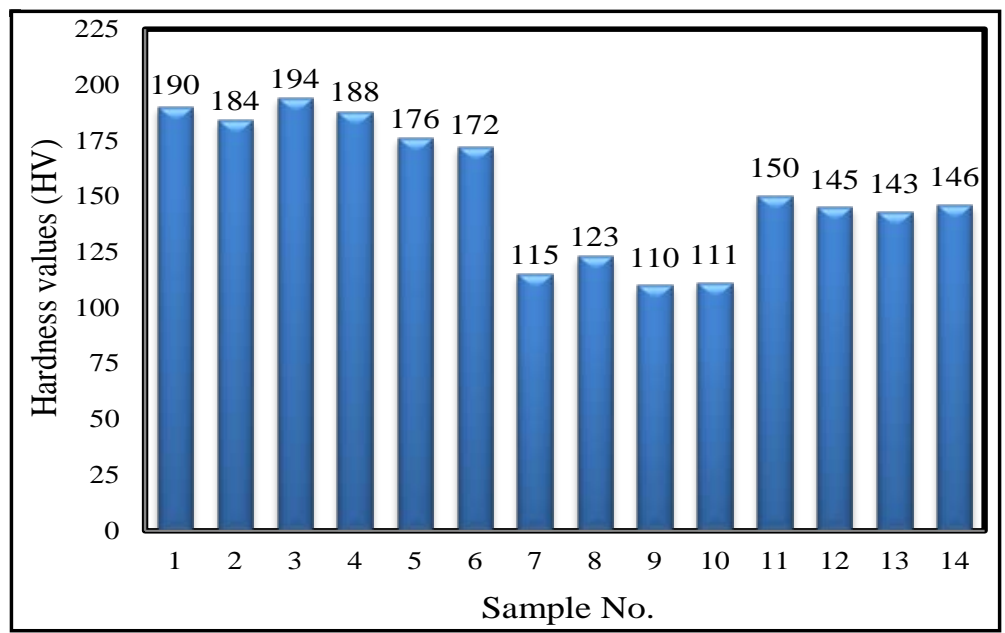

Figure 1. Hardness values of the tested samples.

Table 5. Results of mechanical tests carried on the different specimens of $\mathrm{CuZn} 40 \mathrm{~Pb} 2 \mathrm{al}-$ loys.

\begin{tabular}{|c|c|c|c|c|c|c|c|}
\hline \multirow[t]{2}{*}{$\begin{array}{l}\text { Process } \\
\text { Type }\end{array}$} & \multirow[t]{2}{*}{$\begin{array}{c}\text { Sample } \\
\text { No. }\end{array}$} & \multirow[t]{2}{*}{$\begin{array}{l}\text { Hardness } \\
\text { (HB) }\end{array}$} & \multirow[t]{2}{*}{$\begin{array}{l}\text { Hardness } \\
\text { (Vickers) }\end{array}$} & \multicolumn{2}{|c|}{$\begin{array}{c}\text { Micro-Hardness } \\
\text { (Vickers) after } \\
\text { fracture by tensile test }\end{array}$} & \multirow{2}{*}{$\begin{array}{l}\text { Ultimate } \\
\text { tensile } \\
\text { strength } \\
(\mathrm{MPa})\end{array}$} & \multirow[t]{2}{*}{$\begin{array}{c}\text { Elongation } \\
\%\end{array}$} \\
\hline & & & & Center & Surface & & \\
\hline \multirow{3}{*}{ 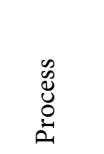 } & 1 & 163.5 & 190 & --- & --- & --- & --- \\
\hline & 2 & 159.5 & 184 & --- & --- & --- & --- \\
\hline & 3 & 166.7 & 194 & --- & --- & --- & --- \\
\hline \multirow{3}{*}{ : } & 4 & 157.6 & 188 & --- & --- & --- & --- \\
\hline & 5 & 151.4 & 176 & --- & --- & --- & --- \\
\hline & 6 & 149.4 & 172 & --- & --- & --- & --- \\
\hline \multirow{4}{*}{ 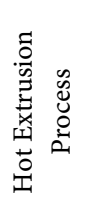 } & 7 & 100.2 & 115 & 170.3 & 163 & 402 & 20.9 \\
\hline & 8 & 100.9 & 123 & 181.3 & 170.33 & 459 & 15 \\
\hline & 9 & 97.2 & 110 & 155 & 150.6 & 404 & 24.3 \\
\hline & 10 & 97.7 & 111 & 168 & 153.33 & 372 & 33 \\
\hline \multirow{4}{*}{ 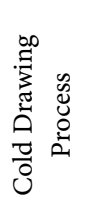 } & 11 & 131.1 & 150 & 191.3 & 180 & 426 & 20.8 \\
\hline & 12 & 127.3 & 145 & 198.3 & 180.3 & 434 & 22 \\
\hline & 13 & 124.6 & 143 & 184.33 & 170.3 & 416 & 15.3 \\
\hline & 14 & 127.8 & 146 & 190 & 182.33 & 452 & 20 \\
\hline
\end{tabular}


mens which provide a rapid and complete comparison between the effect different production stages on the product hardness. These results explain that, the hardness of the first three specimens (i.e. 1,2 and 3) which taken from casting process are more than other samples due to the effect of increasing in some impurities such as iron $(\mathrm{Fe})$ and silicon $(\mathrm{Si})$. The increase of these impurities leads to refine the grain size of these castings and therefore, increases the hardness values. Also, the microstructure of materials influences the properties of the material and variation in microstructure can significantly change the strength, toughness and hardness values [8]. The reasons of impurities rise are due to using the whole charge elements from brass valve recycles. Sample 3 has the highest hardness value compared to the other samples due to its location into the chill zone area of casting billet. The hardness values decreased in extrusion case as in samples 7 to 10 due to the rise in temperature of billet castings during hot extrusion which leads to enlarge the sample structure. The hardness values are increased again during the cold drawing process due to the work hardening process and dislocation density increases which agree with the results of [15].

The micro-hardness test results of extruded and cold drawn samples after fracture by tensile test illustrate that, all hardness values are higher than other samples before tension due to the effect of work hardening. In same time, the hardness values are increased from extrusion to cold drawing processes due to the same reasons mentioned above. The maximum micro-hardness value (i.e. $198 \mathrm{HV}$, see Table 5 and Figure 2) is appeared in sample 12 produced from $100 \%$ recycle and formed by cold drawing process. The comparison between the micro-hardness values in surface and center of tensile test samples (Figure 2) illustrate that, all hardness values in center are more than that in surface. The reasons for this difference can be explained by that the sample grain structures in center are small equiaxed grains, while the circumferential grains are larger due to the fact that the extrusion, drawing and may be torsion during tension makes the circumferential strain degree higher and microstructure finer. In addition, the work hardening of samples during tensile test process also contributed in these differences in micro-hardness values. These differences in hard

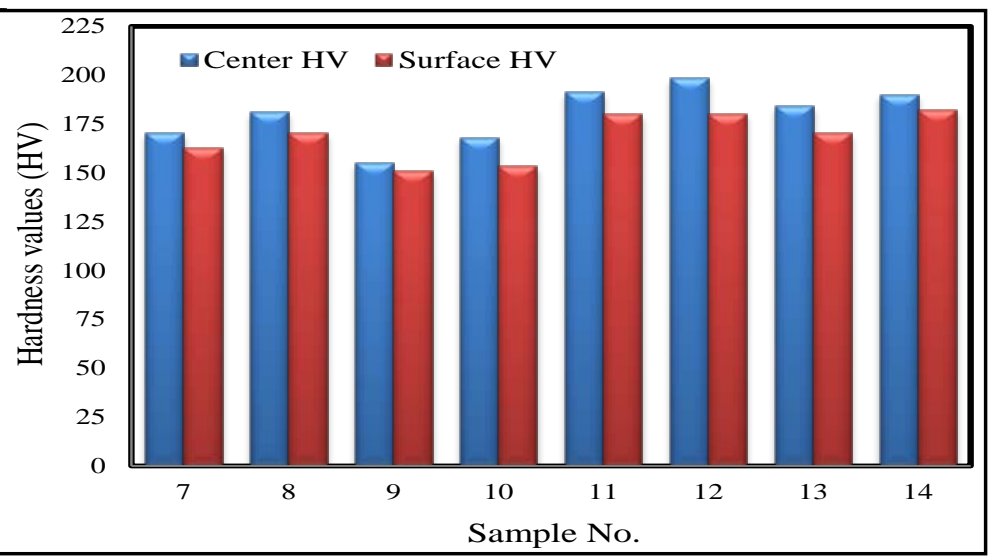

Figure 2. Center and circumferential micro-hardness results of the tested samples. 
ness values between the center or circumferential hardness values and the radial or center hardness values supports also the results obtained by Li et al. [16]. Moreover, the differences in hardness results can be verified by microstructure observations.

\subsection{Tensile and Elongation Test Results}

Figure 3 and Figure 4) and also Table 5 illustrate the results of ultimate tensile strength and elongation percent of extruded and cold drawn leaded brass samples. It can be noted that, the maximum ultimate tensile strength of $459 \mathrm{MPa}$ is appeared for the $8^{\text {th }}$ sample (Figure 3 ). The increasing in these values can be due to the strain hardening. In addition, this sample is already taken from the first alloy that produced from $100 \%$ recycle, which included some percentages of impurities as $\mathrm{Fe}$ and $\mathrm{Si}$; therefore, the mechanical properties as tensile strength can be slightly increased which agree with the results of Jha et al. [17]. The best ultimate tensile strength is appeared by the $14^{\text {th }}$ sample due to using the mixture of pure materials and recycle into melting charge, and due to the cold drawing

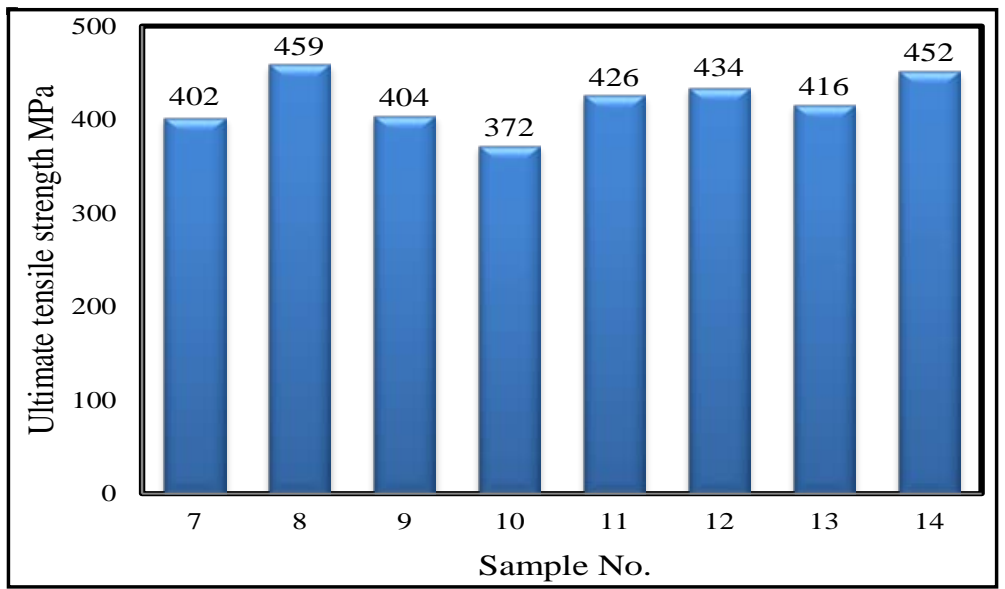

Figure 3. Ultimate tensile strength values of extruded and drawn leaded brass alloy specimens.

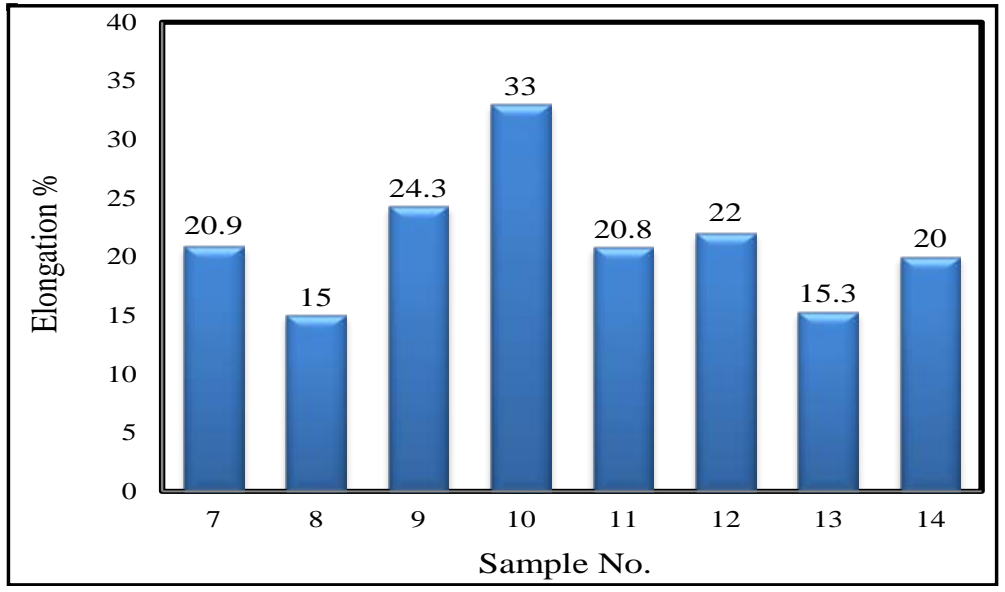

Figure 4. Percentage elongation values of extruded and drawn leaded brass alloy specimens. 
process. The minimum value of tensile test is illustrated by the $10^{\text {th }}$ sample, while the elongation appears of high limit in the same sample.

The elongation values for the extruded and cold drawn samples are affected by the initial charge and the parameters adopted for each stage in the production process. Figure 4 shows the percentage elongation values of extruded and drawn leaded brass alloy specimens. It is worth to note that, the maximum elongation value appeared by the $10^{\text {th }}$ sample which produced from an initial charge contains $30 \%$ pure material using casting process followed by hot extrusion process.

\section{Conclusions}

The effect of raw materials and process parameters during casting, hot extrusion and cold drawing production stages of $\mathrm{CuZn} 40 \mathrm{~Pb} 2$ leaded brass alloy used in gas valves production on the mechanical properties is investigated. The conclusions acquired from the current experimental investigation are as follows:

> Mechanical properties of $\mathrm{CuZn} 40 \mathrm{~Pb} 2$ alloy such as hardness and ultimate tensile strength are principally affected by raw materials and the production parameters used.

> Hardness values are high through casting stage and decreased after hot extrusion and finally increased after cold drawing.

Best ultimate tensile strength appears when the mixture of pure materials and recycle is used into melting charge, and after the cold drawing process.

More improvements in mechanical properties occur by cold forming with the addition of pure materials and some changes in production parameters such as billet preheat temperature and extrusion ram speed.

Micro-hardness values of fractured tensile test specimens of $\mathrm{CuZn} 40 \mathrm{~Pb} 2 \mathrm{al}-$ loys are more than tested after casting, hot extrusion and cold drawing processes.

\section{References}

[1] Konečná, R. and Fintová, S. (2012) Copper and Copper Alloys: Casting, Classification and Characteristic Microstructures. University of Žilina, Slovak Republic.

[2] Bauser, M., Sauer, G. and Siegert, K. (2006) Extrusion. 2nd Edition, ASM International, Ohio. (Translated from Germany by A. F. Castle)

[3] Taha, M.A., El-Mahallawy, N.A., Hammouda, R.M., Moussa, T.M. and Gheith, M.A. (2012) Machinability Characteristics of Lead Free-Silicon Brass Alloy as Correlated with Microstructure and Mechanical Properties. Ain Shams Engineering Journal, 3, 383-392.

[4] Bagherian, E.-R., Fan, Y., Abdolvand, A., Cooper, M. and Frame, B. (2016) Investigation of the Distribution of Lead in Three Different Combinations of Brass Feedstock. Scotland, UK.

[5] Pantazopoulos, G.A. and Toulfatzis, A.I. (2012) Fracture Modes and Mechanical Characteristics of Machinable Brass Rods. Metallography, Microstructure, and Analysis, 1, 106-114. https://doi.org/10.1007/s13632-012-0019-7

[6] Pantazopoulos, G. and Vazdirvanidis, A. (2008) Failure Analysis of a Fractured Leaded-Brass (CuZn39Pb3) Extruded Hexagonal Rod. Journal of Failure Analysis and Prevention, 8, 218-222. https://doi.org/10.1007/s11668-007-9084-7 
[7] Reetz, B. and Reimers, W. (2008) Hot Extrusion of $\alpha$ and $\alpha / \beta$ Brass Alloys. International Journal of Materials Research, 99, 787-794. https://doi.org/10.3139/146.101694

[8] Pernis, R., Kasala, J. and Pernis, I. (2011) Surface Defects of Brass Bars. Faculty of Special Technology, Slovak Republic.

[9] Bodude, M.A., Momohjimoh, I. and Nnaji, R.N. (2015) Mechanical and Microstructural Evaluation of Plastically Deformed Brass. Materials Sciences and Applications, 6, 1137-1144. https://doi.org/10.4236/msa.2015.612112

[10] Davis, J.R. (2001) ASM Specialty Handbook: Copper and Copper Alloys. ASM International, London.

[11] Ashby, M. (2009) Teach Yourself Phase: Diagrams and Phase Transformation. 5th Edition.

[12] Brown, J.R. (1999) Foseco Non-Ferrous Foundry Man's Handbook. 11th Edition.

[13] Annual Book of ASTM standard, ASTM E8M (1987) Metal Test Methods and Analytical Procedures. Section 3, Vol. 03.01, USA.

[14] Wiand, A. (2002) Annual Book of ASTM Standard E140-02. Vol. 03.01, Committee E28 on Mechanical Testing.

[15] Bodude, M.A., Momohjimoh, I. and Nnaji, R.N. (2015) Mechanical and Microstructural Evaluation of Plastically Deformed Brass. Materials Sciences and Applications, 6, 1137-1144. https://doi.org/10.4236/msa.2015.612112

[16] Li, J., Li, F., Zhao, C., Chen, H., Ma, X. and Li, J. (2016) Experimental Study on Pure Copper Subjected to Different Severe Plastic Deformation Modes. Materials Science and Engineering: $A, 656,142-150$.

[17] Jha, S.K., Balakumar, D. and Paluchamy, R. (2015) Experimental Analysis of Microstructure and Mechanical Properties of Copper and Brass Based Alloys. International Journal of Automotive and Mechanical Engineering (IJAME), 11, 2317-2331.

\section{Submit or recommend next manuscript to SCIRP and we will provide best service for you:}

Accepting pre-submission inquiries through Email, Facebook, LinkedIn, Twitter, etc. A wide selection of journals (inclusive of 9 subjects, more than 200 journals) Providing 24-hour high-quality service

User-friendly online submission system Fair and swift peer-review system Efficient typesetting and proofreading procedure Display of the result of downloads and visits, as well as the number of cited articles Maximum dissemination of your research work

Submit your manuscript at: http://papersubmission.scirp.org/

Or contact wjet@scirp.org 